\title{
Application Mycorrhizal Glomus sp 3 with P Fertilizer to Increase Rice Production of SRI Method and Intensified Soil Nutrient Content
}

\author{
N Elita ${ }^{1}$, E Susila $^{2}$, Y Yefriwati ${ }^{3}$ \\ Department of Food Crop Cultivation, State Agricultural Polytechnic Payakumbuh, \\ Tanjung Pati Highway 7 km District District Limapuluh Kota harau 26271* \\ \{ ekasusila38@yahoo.com², yefriwati@gmail.com $\left.{ }^{3}\right\}$
}

\begin{abstract}
Rice cultivation in Indonesia with conventional systems using stagnant water and high inorganic fertilizers especially $\mathrm{P}$ causes the death of beneficial microorganisms and degraded land. The new method of rice cultivation is the SRI (The System of Rice Intensification) method in the vegetative phase of aerobic conditions, allowing live and active lifelong microorganisms, one of them is Arbuscular Fungi Mikoriza (AFM). Indigenous AFM type Glomus sp 3 taken from rhizosfir rice plants SRI method is more adaptive and effective. The objective of this research is to obtain the dosage of Glomus sp 3 indigenous formulations and $P$ fertilizer efficiency on the increase of rice production of the SRI method and the improvement of intensified soil nutrient content. The research was conducted in farmers' fields in Taram, Harau Sub-district. The design used is the Factorial Random Block Design. The first factor is the dose of indigenous AFM formulation. The second factor is the efficiency of $\mathrm{P}$ fertilizer with 3 replications. The results of mycorrhizal dose were significantly different in a number of tillers. $\mathrm{P}$ fertilizer efficiency of $50 \%$ gives a real effect on plant height and number of tillers. Giving Glomus sp $320 \mathrm{~kg} / \mathrm{ha}$ increased the number of tillers 31.22 seedlings and rice yield 8 tons/ha. The best $\mathrm{P}$ fertilizer efficiency at $50 \%$ dose of rice production reached 9.83 tha, the result of this study is much higher than previous research. The increase of soil nutrient content of paddy field intensification from initial nutrient analysis before research with after research is shown by increasing quality of soil chemical properties especially $\mathrm{pH}$ reach $19,80 \%$, organic matter until $85,12 \%, \mathrm{~N}$ total reach $44,44 \%$, P- available $77.77 \%$, K-dd 58.33\%, and KTK 24.8\%. The conclusion of the increase of rice production of the SRI method with mycorrhizal Glomus sp $320 \mathrm{~kg} / \mathrm{ha}$ and P fertilizer efficiency of $50 \%$ so that the increase of paddy production is $93,50 \%$. The result of soil nutrient analysis intensified the increase of soil fertility status from low to moderate.
\end{abstract}

Keywords: AMF, Mycorrhiza, SRI, indigenous, Glomus sp 3

\section{Introduction}

The intensive rice field in Indonesia for more or less 30 years of rice cultivation is managed by a conventional system dominated by high inorganic fertilizers especially $\mathrm{P}$ cause land 
degradation. The conventional systems using aerobic (stagnant water) causes the death of beneficial microorganisms, resulting in increasingly critical land [1].

It is necessary to change rice cultivation for the intensification of paddy fields. The new method of rice cultivation with aerobic system is the SRI (The System of Rice Intensification) method. SRI uses an aerobic system during the vegetative phase, enabling life-changing and active microorganisms, and availability abundantly[2].

One of the beneficial microbes that live active in aerobic conditions is mycorrhiza. The use of indigenous mycorrhizae is more adaptive and effective in its development so that its ability to absorb nutrients is higher and increases the rate of plant growth [3]. Mycorrhiza is a biological agent that can increase the efficiency of chemical fertilizer (an organic) because it can increase the availability of soil nutrients [4],[5].

Mycorrhiza can improve environmental conditions and adapt to environmental conditions that are less suitable for growth [6],[7]. Mycorrhizas combined with rhizosphere Cryptococcus flavus increase P uptake in corn plants [8]. The mycorrhizal hyphae has a strong effect on the high growth of sunflower plants

Mycorrhizas combined with rhizospheric microorganisms increased nutrient uptake of maize compared to control. This supports the occurrence of changes in metabolic pathways identified during the symbiotic interaction of increased growth and nutrient uptake in plants [9]

Compost and mycorrhizal applications have a significant impact on soil nutrient and plant growth. Mycorrhiza has a relatively small impact on plant growth, but plants grow better with increasing supply of compost [10]

The study of indigenous mycorrhizal identification in rhizosphere of rice plants is still very limited, as it is believed that there is more mycorrhiza on dry land. Rice cultivation SRI method of aerobic conditions allows mycorrhizal life and improve the condition of paddy fields that have been happening land degradation due to the application of high chemical fertilizers.

The purpose of this study is to obtain the appropriate dosage of Glomus sp 3 indigenous formulation to optimize $\mathrm{P}$ fertilizer to increase rice production of SRI method and improvement of intensified soil nutrient content

\section{Research Methods}

Wetland intensification of rice fields in Indonesia is a serious problem, as it is an accumulation of various activities, including inorganic fertilization activities are continuous so that the accumulation of fertilizers, especially $\mathrm{P}$, the provision of pesticides and burning residual crops that kill off useful microorganisms

This activity leads to the degradation of soil quality so that the area of critical land continues to grow.

Rice cultivation by the SRI method using a vegetative phase of aerobic conditions allows the microorganisms to live and abundance.

One of them microbes is mycorrhiza. Mycorrhiza infects rice plants through root exudates causing an increase in nutrient uptake by roots. Bhattacharyya et al., (2016) states that aerobic conditions support soil microbes and their abundance abundantly through root exudates. Rice crops through root exudate microbial activity of soil to roots in the form of biological absorption of $\mathrm{P}$ with rhizosphere, the presence of mycorrhiza infection to plant roots that increase the variation and amount of nutrients absorbed the roots [12]. 


\subsection{Time and Place}

Research conducted from February to June 2017. The implementation of the research will be conducted in the laboratory of Microbiology and Land State Polytechnic Payakumbuh, and farmers in Taram sub-district Harau District Limapuluh City

\subsection{Materials and Tools}

The materials used are Agam river sand, Mycorrhizal species Glomus sp 3, Arginin 1\%, rice seed, Urea, SP36, and $\mathrm{KCl}$ fertilizer. The tools used are hoes, stoves, pans, Petri dish.

\subsection{Experimental Design}

This research was conducted according to factorial randomized block design as the first factor of indigenous AFM formulation dose: $\left(10 \mathrm{ha}^{-1}, 30 \mathrm{~kg} \mathrm{ha}^{-1}\right.$ and $\left.50 \mathrm{~kg} \mathrm{ha}^{-1}\right)$. The second factor of P fertilizer efficiency consisted of 4 levels: P0 (without P fertilizer), P1 (25\% recommendation), P2 (50\% recommendation) and $\mathrm{P} 3$ (75\% recommendation) with 3 replications. To examine the effect of treatment on the observed response, the analysis of variance using the Statistical Analysis System (SAS) program. Furthermore, Duncan Multiple Range Test Duncan multiple areas tests to see the difference of treatment at a 5\% level.

\subsection{Procedures}

Indigenous Arbuscular Fungi Mycorrhizal with Agam sand formulation. The location of the paddy field used is farmers in Taram District, Harau District. The paddy field was laid, made a trial plot of $2.1 \times 2.1 \mathrm{~m}$ of 36 plots. Distance between plots in blocks $0.5 \mathrm{~m}$ and distance between replicates $1 \mathrm{~m}$. The paddy fields are firstly crushed by destroying the ground grain using hand tractors. The job of destroying the grain of the soil is carried out while inundating the land with irrigation water and throwing out all the weeds in each crater.

\subsection{Provision of treatment}

The mycorrhizal formulation was adjusted according to the treatment after the finished field was treated

\subsection{Seedlings}

Seedlings are made on a seedbed (plastic tub) that already contains the composition of soil and manure with a ratio of 1:1 as thick as $5 \mathrm{~cm}$. Seeds that have been soaked for 1 night and continued with 1 night's ripening then sown on the seed medium at sufficient density (approximately 300-350 eggs). Rice seeds that are 12 days old or already have 2 full leaves (2 phyllochron) ready to be planted into the plot.

\subsection{Planting}

Seedlings from nurseries were planted 1 stem per planting point with a distance of $30 \times 30$ $\mathrm{cm}$ in existing plot (49 clumps of plants). 


\section{$2.8 \quad$ Fertilization}

Fertilization is given half the recommended dose with Urea $\left(150 \mathrm{~kg} \mathrm{ha}^{-1}\right.$ or $\left.63 \mathrm{~g} / \mathrm{plot}\right)$ and $\mathrm{KCL}\left(50 \mathrm{~kg} \mathrm{ha}^{-1}\right.$ or $21 \mathrm{~g} / \mathrm{plot}$ ) is given at planting time and urea is given 2 times (beginning and 30 days) spread. Fertilizer SP-36 given according to treatment.

\subsection{Irrigation}

After young seedlings are planted in the plot (there are 49 clumps of plants), the water is set as high as $1 \mathrm{~cm}$ above the soil surface to dry for about 5 days, then dampened again in the afternoon until the soil wet and let it to dry broke. This work repeats up to enter the early period of flowering. Enter the flowering period, the water level is maintained up to $3 \mathrm{~cm}$ above the soil surface until the reproductive period comes. Starting from the flowering to the high physiological mature water maintained $5 \mathrm{~cm}$. Ten days before the harvest the land left to dry

\subsection{Maintenance}

Further treatment of plants is mainly weeding weeds because weeds are more easily grown on SRI method due to aerobic system. Once a week weed out the weeds and buried them by using a caterer so that the soil air conditioning to be better.

\subsection{Harvest and Post Harvest}

Harvest is done after the plant meets the harvest criteria that is 110 days old, marked the leaves have begun to yellow and dry, panicles have ducked, the grain has full and yellow yellow, and moisture content of less than $30 \%$.

Post-harvest activities include threshing and drying in the sun so that the grain water content reaches $14 \%$. Harvesting is done with a sickle.

Observation: (1). Plant height (cm), (2) Number of panicles per hill (malai), (3) Number of grains per panicle, (4) Number of unpaid grains per panicle

is calculated from 3 panicles in a clump of plants, (5) Weight of 1000 seeds (g), (6) Production of dry grain per hectare (ton).

Observation of wetland soil quality on soil chemical properties is $\mathrm{pH} H 2 \mathrm{O}$ 1: 2,5 (electrometric method) N-total content (Kjeldahl method), P-available (Bray Method 1), CEC $(\mathrm{NH} 4 \mathrm{COOH} 3 \mathrm{pH} 7)$, at the beginning of the study and end research.

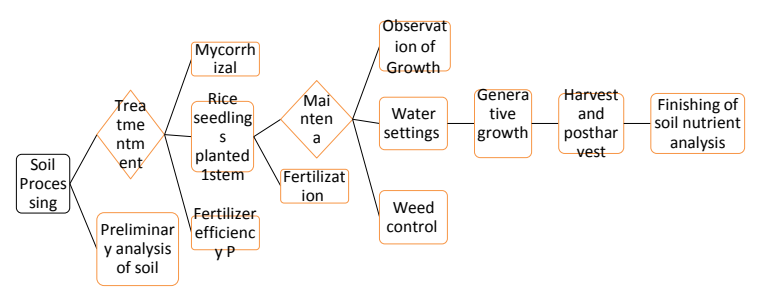

Figure 1: Procedures for conducting research 


\section{Result And Discussion}

Arbuscular mycorrhizal fungi can play a role in reducing soil erosion. Hyphal of mycorrhizal fungi that combine with plant roots play a role in retaining ground flow so that soil loss can be reduced [11], [13], [14].

Mycorrhizal fungi play an important role in the nutrient cycle and can reduce nutrient losses after washing due to rain [15]. Mycorrhizal fungi can reduce nutrient losses especially $\mathrm{N}$ elements and the effect of this $\mathrm{N}$-dependent loss on plants is highly dependent on the species of host plants and the mycorrhizal fungi species present in the soil [16], [17].

The arbuscular mycorrhizal fungus can improve the sustainability of plant and soil systems by reducing nutrient uptake nutrient loss. The arbuscular mycorrhizal fungus can reduce the release of reactive $\mathrm{P}$ and $\mathrm{P}$ is not reactive until $31 \%$, increases the soil nutrient $\mathrm{P}$ content up to $15 \%$ and can increase the mobility of $\mathrm{P}$ soil by $18 \%$ [18].

The effect of dosing Glomus sp 3 and fertilizer efficiency of $\mathrm{P}$ vegetative growth of the rice plant of the SRI method is presented in Table 1.

Table 1. Effect Of Glomus Sp 3 Dose Formulation And P Fertilizer Efficiency On Vegetative Growth On Rice Sri Method In Field

\begin{tabular}{|c|c|c|}
\hline Main Factor I & Plant height & $\begin{array}{l}\text { Number } \\
\text { Tillers }\end{array}$ \\
\hline Glomus sp 3 Formulation Dose & $(\mathrm{cm})$ & (Tillers) \\
\hline M1 (10 kg ha $\left.{ }^{-1}\right)$ & 111,39 & $28,28^{\mathrm{B}}$ \\
\hline M2 (20 kg ha-1) & 114,22 & $31,22^{\mathrm{A}}$ \\
\hline M3 $\left(30 \mathrm{~kg} \mathrm{ha}^{-1}\right)$ & 113,56 & $29,72^{\mathrm{A}}$ \\
\hline \multicolumn{3}{|l|}{ Main Factor I II } \\
\hline \multicolumn{3}{|l|}{ The dose of Fertilizer $\mathrm{P}$} \\
\hline $\mathrm{P} 0\left(0 \mathrm{~kg} \mathrm{ha}^{-1}\right)$ & $109,19^{\mathrm{c}}$ & $27,52^{\mathrm{c}}$ \\
\hline P1 $(25 \%)$ & $112,15 \mathrm{bc}$ & 28,74 bc \\
\hline P2 $(50 \%)$ & $117,93^{\mathrm{a}}$ & $32,81^{\text {a }}$ \\
\hline P3 $(75 \%)$ & $112,96^{\mathrm{b}}$ & $29,89^{\mathrm{b}}$ \\
\hline
\end{tabular}

The numbers in the columns followed by unequal small letters differ significantly at the $5 \%$ real level with DNMRT advanced tests

In Table 1 it can be seen that the dose of Glomus sp 3 isolate formulation did not give significant effect to plant height, but it was significantly different in the number of tillers. The dose of $\mathrm{P}$ fertilizer gives a real effect on plant height and number of tillers. However, the dosing of Glomus sp 3 formulation further enhances the growth of plant height and number of tillers compared with the efficiency without $P$ fertilizer [18]. Thus, the formulation of Glomus sp 3 is more effective in increasing the growth of plant height and number of tillers of rice plants. Increased nutrient content in wetland intensification as a result of Fungi Glomus sp 3 and $\mathrm{P}$ fertilizer (Table 1) has increased the growth of plant height and number of saplings.

The arbuscular mycorrhizal fungus is given to the plant can enhance plant growth, protect host plants from various pest and disease attacks, and neutralize plant interactions from extreme environmental conditions [19],.

Growth of plant height and number of tillers of rice plants affected by nutrients absorbed by the roots of rice plants. Fungi mikoriza Glomus sp 3 able to increase the content of nutrients in rice field intensification rice planted with SRI method 
(Table 1). Fungi mikoriza Glomus sp 3 can increase nutrient nutrients especially phosphate and other macronutrients such as $\mathrm{N}$, and $\mathrm{K}$ which contribute to vegetative growth of plants[20]

Table 2. Effect Of Glomus Sp 3 Dosage Formulation And P Fertilizer Dose On Generative Growth In Sri Rice Method In Field

\begin{tabular}{|c|c|c|c|c|c|}
\hline Main Factor I & $\begin{array}{l}\text { Number of } \\
\text { panicles }\end{array}$ & $\begin{array}{c}\text { Number of } \\
\text { Grain }\end{array}$ & $\begin{array}{l}\text { Number of } \\
\text { Pelleted } \\
\text { grains }\end{array}$ & $\begin{array}{l}\text { Weight } \\
1000 \\
\text { Grains } \\
\end{array}$ & $\begin{array}{l}\text { Production of } \\
\text { hectare }\end{array}$ \\
\hline Glomus sp 3 & (Panicles) & (Grain) & (Grain) & (Gram) & (Ton) \\
\hline \multicolumn{6}{|l|}{ Formulation Dose } \\
\hline M1 $\left(10 \mathrm{~kg} \mathrm{ha}^{-1}\right)$ & $23,19^{b}$ & 152,36 & $129,36^{\mathrm{b}}$ & 19,95 & $6,73^{\mathrm{b}}$ \\
\hline M2 $\left(20 \mathrm{~kg} \mathrm{ha}^{-1}\right)$ & $24,31^{\mathrm{a}}$ & 160,94 & $142,61^{\mathrm{a}}$ & 20,39 & $8,00^{\mathrm{a}}$ \\
\hline M3 (30 kg ha-1) & $21,97^{b}$ & 159,94 & $136,11^{\mathrm{a}}$ & 20,37 & $6,84^{\mathrm{b}}$ \\
\hline \multicolumn{6}{|l|}{ Main Factor II } \\
\hline \multicolumn{6}{|l|}{ Dose of Fertilizer P } \\
\hline $\mathrm{P} 0\left(0 \mathrm{~kg} \mathrm{ha}^{-1}\right)$ & $21,33^{\mathrm{C}}$ & $149,81^{\mathrm{BC}}$ & $109,81^{\mathrm{C}}$ & $19,45^{\mathrm{C}}$ & $5,08^{\mathrm{D}}$ \\
\hline $\mathrm{P} 1(25 \%)$ & $22,22^{\mathrm{B}}$ & $150,19^{\mathrm{B}}$ & $132,41^{\mathrm{B}}$ & $20,02^{\mathrm{B}}$ & $6,54^{\mathrm{C}}$ \\
\hline P2 $(50 \%)$ & $25,70^{\mathrm{A}}$ & $169,44^{\mathrm{A}}$ & $165,00^{\mathrm{A}}$ & $20,93^{\mathrm{A}}$ & $9,83^{\mathrm{A}}$ \\
\hline P3 (75\%) & $23,37^{\mathrm{B}}$ & $161,56^{\mathrm{B}}$ & $136,89^{\mathrm{B}}$ & $20,55^{\mathrm{AB}}$ & $7,31^{\mathrm{B}}$ \\
\hline
\end{tabular}

The numbers in the columns followed by unequal small letters differ significantly at the $5 \%$ real level with DNMRT advanced tests

In Table 2 the dosage formulation Glomus sp 3 gave a significant effect on the number of panicles, the number of unpaid grains, 1000 grain weight and the production of a hectare, but not significantly different from the number of grains of the panicle. The dose of $\mathrm{P}$ fertilizer gives a real effect on all generative observations of rice crops [21].

The observations shown in Table 2 on the SRI rice crop production component as presented in Table 4 are found to be quite varied. In the observation of the number of panicles obtained the highest yield of Glomus sp $320 \mathrm{~kg} \mathrm{ha}^{-1}$ (M2), but on the number of grains per panicle is not significantly different. The quantity of unpaid grain dosage formulation of Glomus sp $320 \mathrm{~kg}$ $\mathrm{ha}^{-1}$ was not significantly different from $30 \mathrm{~kg} \mathrm{ha}^{-1}$ and the weight of 1000 grains was not significantly different. The highest yield of hectare was obtained at the dose of Glomus sp 320 $\mathrm{kg} \mathrm{ha}^{-1}$ (M2) formulation which differed significantly from $10 \mathrm{~kg} \mathrm{ha}^{-1}$ (M1) and $30 \mathrm{~kg} \mathrm{ha}^{-1}$ (M3). It can be stated here that the dosage formulation of Glomus sp $320 \mathrm{~kg} \mathrm{ha}^{-1}$ in rice plants with the SRI method can give the best result to rice production.

FMA applied to plants will release hyphae that will infect plant roots. The hyphae that emerge from the germinated spores will look for the root exudate released by the plant as an AFM feedstock to penetrate the roots [22]. The hyphae that have penetrated the roots will develop within and between the root cells, then hyphae will change as a place of exchange of nutrients with photosynthesis called arbuscules [23].

In addition, AFM in root cells produces exponentially developed external hyphae of hifa colonization that grows and develops through the roots of the plant so as to expand the absorption area and increase nutrient uptake by plants, especially phosphate (P) [24]. The external hyphae will help bring the nutrients closer from the rhizosphere zone to the host plant so that the nutrient absorption is more optimal and the growth and development of the plant becomes faster [25]. These conditions affect the yield components and yield of rice crops to increase [26].

The yield of fertilizer P 50\% (P2) to the yield component shown (Table 2) showed the highest yield for all components yield of panicle per hill, the number of grain per panicle, the 
number of unpaved rice per panicle, 1000 grain weight and production per hectare and significantly different With a dose of fertilizer P0 $\left(0 \mathrm{~kg} \mathrm{ha}^{-1}\right), \mathrm{P} 1(25 \%)$ and P3 $(75 \%)$.

This indicates that the higher dose of $\mathrm{P}$ fertilizer given is not always followed by the higher response of the SRI rice yield component observed [27], [28]. Mycorrhizas operate on the biological, chemical, and physical processes that determine soil fertility [29].

The result of soil chemical properties analysis of the effect of Glomus sp 3 is presented in Table 3.

Table 3. The Result Of Initial Soil Analysis And The End Of The Study After Treated Dose Isolate Glomus Sp 3 Indigenous And Fertilizer Efficiency P

\begin{tabular}{|c|c|c|c|c|c|c|c|c|c|c|c|c|c|}
\hline \multirow{2}{*}{$\begin{array}{l}\text { The } \\
\text { characteristics } \\
\text { of soil chemistry }\end{array}$} & \multirow{2}{*}{$\begin{array}{l}\text { Initia } \\
1 \text { soil } \\
\text { analy } \\
\text { sis }\end{array}$} & \multicolumn{12}{|c|}{ Treatment } \\
\hline & & $\mathrm{M}_{1} \mathrm{P}_{0}$ & $\begin{array}{l}\mathrm{M}_{1} \\
\mathrm{P}_{1}\end{array}$ & $\mathrm{M}_{1} \mathrm{P}_{2}$ & $\mathrm{M}_{1} \mathrm{P}_{3}$ & $\mathrm{M}_{2} \mathrm{P}_{0}$ & $\mathrm{M}_{2} \mathrm{P}_{1}$ & $\mathrm{M}_{2} \mathrm{P}_{2}$ & $\mathrm{M}_{2} \mathrm{P}_{3}$ & $\mathrm{M}_{3} \mathrm{P}_{0}$ & $\mathrm{M}_{3} \mathrm{P}_{1}$ & $\mathrm{M}_{3} \mathrm{P}_{2}$ & $\mathrm{M}_{3} \mathrm{P}_{3}$ \\
\hline pH H2O (1:1) & 5,05 & 5,55 & $\begin{array}{c}5,6 \\
5 \\
\end{array}$ & 5,80 & 5,80 & 5,80 & 5,85 & 6,05 & 5,90 & 5,75 & 5,85 & 6,00 & 5,85 \\
\hline $\begin{array}{l}\text { Bahan organic } \\
(\%)\end{array}$ & 1,21 & 1,41 & $\begin{array}{c}1,9 \\
0 \\
\end{array}$ & 1,41 & 2,24 & 1,41 & 1,41 & 2,24 & 2,24 & 1,90 & 1,41 & 2,24 & 2,24 \\
\hline $\begin{array}{l}\text { N-total } \\
(\text { kjeldahl })(\%)\end{array}$ & 0,09 & 0,11 & $\begin{array}{c}0,1 \\
1 \\
\end{array}$ & 0,13 & 0,12 & 0,11 & 0,10 & 0,12 & 0,13 & 0,10 & 0,11 & 0,12 & 0,13 \\
\hline $\begin{array}{l}\text { P-tersedia } \\
(\text { Bray-2) }(\mathrm{ppm})\end{array}$ & 9 & 12 & 12 & 13 & 13 & 12 & 12 & 15 & 15 & 12 & 12 & 15 & 16 \\
\hline $\begin{array}{l}\text { K-dd (me/100g } \\
\text { tanah) }\end{array}$ & 0,12 & 0,20 & $\begin{array}{c}0,1 \\
9 \\
\end{array}$ & 0.15 & 0,17 & 0,23 & 0,16 & 0,12 & 0,13 & 0,19 & 0,19 & 0,15 & 0,16 \\
\hline $\begin{array}{l}\text { KTK (me/100g } \\
\operatorname{tanah)}\end{array}$ & 12,5 & 12,6 & $\begin{array}{c}12, \\
9 \\
\end{array}$ & 15,5 & 14,8 & 13,4 & 15,2 & 16,2 & 15,1 & 14,9 & 14,3 & 15,6 & 14,2 \\
\hline
\end{tabular}

\section{$3.1 \quad$ pH H2O}

The results of this study provide an interesting indication of an increase in soil chemical properties by treatment of Glomus sp 3 inoculant doses (Table 1 and Table 2). In Table 2 above it was seen that soil $\mathrm{pH}$ rose from low to moderate with a range between 5.05 to 6.05 and the dosage of Glomus sp 3 formulations and 50\% fertilizer efficiency (M2P2) gave the highest soil $\mathrm{pH}$. Soil $\mathrm{pH}$ is very suitable for rice cultivation in dry and humid conditions. This condition is suitable for the AFM fungus to activate its mycelium. The results showed that AFM Glomus sp 3 and $\mathrm{P} 50 \%$ fertilizer were able to increase the highest soil $\mathrm{pH}$ from other treatments.

The provision of AMF can increase soil $\mathrm{pH}$ and improve soil fertility. This is because with the activity and metabolism AMF produces and releases organic compounds that play a role in binding metal cations that cause soil acidity so that soil $\mathrm{pH}$ increases [30].

\subsection{Organic materials}

Giving Glomus sp 3 and P fertilizer efficiency can increase the availability of soil organic matter soils Ultisols (Table 1 and Table 2). Increased high organic matter was found in combination of M2P2 (20 kg ha mikoriza and 50\% efficiency of P fertilizer), M2P3 (20 kg ha-1 mycorrhiza and efficiency 75\% P fertilizer), M3P2 (30 kg ha ${ }^{-1}$ mycorrhiza and 50\% efficiency of P fertilizer) and M3P3 (30 kg ha ${ }^{-1}$ of mycorrhiza and efficiency of $75 \% \mathrm{P}$ fertilizer). This indicates an increase in mycorrhizal doses and the efficiency of $\mathrm{P}$ fertilizer can increase the availability of soil organic matter [31]. 


\section{$3.3 \quad$ N-total}

Giving Glomus sp 3 and P fertilizer efficiency were able to increase N-total in Ultisols soil that affected the number of tillers (Table 3 ) and the yield and yield component of rice plant by SRI method (Table 3). There are the giving of AFM in plant roots is able to increase N-total because AFM has the ability to accumulate and mobilize $\mathrm{N}$ from organic material sources. Colonization of mycorrhizae was significantly correlated with total mineral content of the seeds [26].

\subsection{P-available}

The highest available P-is found in M3P3 treatment (30 kg ha ${ }^{-1}$ of mycorrhiza and fertilizer efficiency P 75\%). This suggests that the effect of the dose of AFM Glomus sp 3 absorbed to plant roots through the mycelium of AFM still increases P-available soil (Table 1 and Table 2). In the M2P2 treatment (20 kg / ha of mycorrhiza and 50\% P fertilizer efficiency) P-available increased up to $15 \mathrm{ppm}$. At the same time affect the components of crop yield and rice production by SRI method (Table 3). The absorption of phosphate with the help of the myconia AFM Glomus sp 3, the fertilization efficiency becomes higher with residual effect still higher than the level of P-available of the original soil. The process is all independent of the role of higher soil cation exchange capacity (CEC) of the other as a result of the treatment of the dose of $20 \mathrm{~kg}$ / ha AFM Glomus sp 3, combined with a 50\% P-available dose (M2P2) with sufficient $\mathrm{P}$ and Improved soil CEC will encourage optimal seed initiation and will produce maximally.

According to H.M, John, et al, the plant shoot is responsible for removing the C nutrient substrate, the roots function for the removal of $\mathrm{N}$ and $\mathrm{P}$ substrate, and the mycorrhiza also serves to absorb $\mathrm{N}$ and $\mathrm{P}$ nutrient substrate

\subsection{K-dd}

The dosage of Glomus sp 3 and the efficiency of $\mathrm{P}$ fertilizer increased against K-dd of Ultisols soil (Table 1 and Table 2), but in M2P2 treatment the effect of Glomus sp 3 mycelium and $\mathrm{P}$ fertilizer efficiency was approaching the initial K-dd Ultisols, This shows the effect of absorption capacity of mycorrhizal mycelium which gives a big influence on the number of tillers and the components of rice crops SRI method [32].

\subsection{Cation Exchange Capacity (CEC)}

Giving dose Glomus sp 3 and fertilizer efficiency P increase to soil Cert Ultisols (Table 1 and Table 2). CEC in Ultisols soil is low (Table 3). Stated that the high CEC is influenced by soil properties and characteristics of soil reaction or soil $\mathrm{pH}$, soil texture or clay amount, clay mineral type, organic matter and calcification and fertilization.

The results showed a significant effect of the combination of dry olive residue (DOR) inoculation and mycorrhizal bioconversion on wheat growth and elemental mobility. Effect on soil chemical properties increased soil $\mathrm{pH}$, the mobility of $\mathrm{Cd}, \mathrm{Cu}, \mathrm{Fe}, \mathrm{Mn}, \mathrm{P}, \mathrm{Pb}$, and $\mathrm{Zn}$ decreased significantly ( $\mathrm{r}$-value between -0.36 and -0.46 ), while $\mathrm{Ca}$ and $\mathrm{Mg}$ mobility increased $(r=0.63$, and $r=0,51),[33],[34]$. 


\section{Conclusions}

Conclusion of Glomus sp $320 \mathrm{~kg} /$ ha in rice plant SRI method increased the number of tillers reached 31.22 tillers and was able to achieve paddy yield 8 ton / ha .. The higher efficiency of $\mathrm{P}$ fertilizer is not always followed by the increasing of growth and yield component of rice crop . The best $\mathrm{P}$ fertilizer efficiency at a $50 \%$ dose recommendation that gives rice production reaches $9.83 \mathrm{t}$ ha, thus an increase of $93.50 \%$ compared with no $\mathrm{P}(\mathrm{P} 0)$ fertilizer.

Result of analysis of intensified rice field soil with SRI method with Glomus sp 3 indigenous and $\mathrm{P}$ fertilizer efficiency on Ultisols soil increase of soil fertility status from low to medium is much higher than previous research result, indicated by increasing quality of soil chemical properties especially $\mathrm{pH}$ reached $19.80 \%$, organic matter up to $85.12 \%$, N-total reached $44.44 \%$, P-available $77.77 \%$, K-dd reached $24.8 \%$

\section{Acknowledgments}

This paper was supported and funded by DRPM RISTEK DIKTI and P3Mof State Agriculture Polytechnic of Payakumbuh, West Sumatra, Indonesia.

\section{References}

[1] S. CHES, E. Yamaji, and J. Tsurui, "Comparison of System of Rice Intensification (SRI) Practices in Irrigated and Rainfed Areas of Cambodia," Int. J. Environ. Rural Dev., vol. 3, no. 1, pp. 207-212, 2012.

[2] E. Styger, G. Aboubacrine, M. A. Attaher, and N. Uphoff, "The system of rice intensification as a sustainable agricultural innovation: Introducing, adapting and scaling up a system of rice intensification practices in the Timbuktu region of Mali," Int. J. Agric. Sustain., vol. 9, no. 1, pp. 67-75, 2011.

[3] S. Trouvelot, L. Bonneau, D. Redecker, D. van Tuinen, M. Adrian, and D. Wipf, "Arbuscular mycorrhiza symbiosis in viticulture: a review," Agronomy for Sustainable Development, vol. 35, no. 4. pp. 1449-1467, 2015.

[4] S. D. Veresoglou, B. Chen, and M. C. Rillig, "Arbuscular mycorrhiza and soil nitrogen cycling,” Soil Biology and Biochemistry, vol. 46. pp. 53-62, 2012.

[5] J. N. Quinton, G. Govers, K. Van Oost, and R. D. Bardgett, "The impact of agricultural soil erosion on biogeochemical cycling," Nat. Geosci., vol. 3, no. 5, pp. 311-314, May 2010.

[6] P. Jeffries and J. M. Barea, "Arbuscular mycorrhiza: A key component of sustainable plant-soil ecosystems," in Fungal Associations, 2nd Edition, vol. 9, 2012, pp. 51-75.

[7] A. Hodge and K. Storer, "Arbuscular mycorrhiza and nitrogen: implications for individual plants through to ecosystems," Plant Soil, vol. 386, no. 1-2, pp. 1-19, Jan. 2015.

[8] A. Rai, S. Rai, and A. Rakshit, "Mycorrhiza-mediated phosphorus use efficiency in plants," Environ. Exp. Biol., vol. 11, pp. 107-117, 2013.

[9] F. Dhawi, R. Datta, and W. Ramakrishna, "Proteomics provides insights into biological pathways altered by plant growth promoting bacteria and arbuscular mycorrhiza in sorghum grown in marginal soil," Biochim. Biophys. Acta - Proteins Proteomics, vol. 1865, no. 2, pp. 1-9, 2017.

[10] V. Cozzolino, V. Di Meo, H. Monda, R. Spaccini, and A. Piccolo, "The molecular characteristics of compost affect plant growth, arbuscular mycorrhizal fungi, and soil 
microbial community composition,” Biol. Fertil. Soils, vol. 52, no. 1, pp. 15-29, Jan. 2016.

[11] L. Bhattacharyya, A. Nath, L. Handique Bhattacharyya, P. N. Bhattacharyya, V. Parkash, and B. Sharma, "Comparative assessment of arbuscular mycoorhizal fungi (AMF) associated with Oroxylum indicum L. (Kurz.)- an ethno-medicinal plant of N. E. India," Ann. Plant Sci., vol. 5, no. 10, pp. 1436-1441, 2016.

[12] M. C. Rillig, C. A. Aguilar-Trigueros, J. Bergmann, E. Verbruggen, S. D. Veresoglou, and A. Lehmann, "Plant root and mycorrhizal fungal traits for understanding soil aggregation," New Phytologist, vol. 205, no. 4. pp. 1385-1388, 2015.

[13] J. P. W. Young, "Genome diversity in arbuscular mycorrhizal fungi," Current Opinion in Plant Biology, vol. 26. pp. 113-119, 2015.

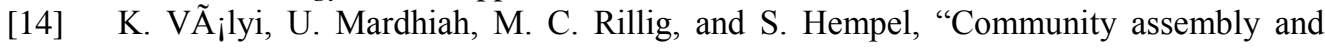
coexistence in communities of arbuscular mycorrhizal fungi," ISME Journal, vol. 10, no. 10. pp. 2341-2351, 2016.

[15] A. B. Cobb et al., "The role of arbuscular mycorrhizal fungi in grain production and nutrition of sorghum genotypes: Enhancing sustainability through plant-microbial partnership," Agric. Ecosyst. Environ., vol. 233, pp. 432-440, 2016.

[16] N. Wurzburger and E. N. J. Brookshire, "Experimental evidence that mycorrhizal nitrogen strategies affect soil carbon," Ecology, vol. 98, no. 6, pp. 1491-1497, 2017.

[17] C. Terrer et al., "Response to Comment on "Mycorrhizal association as a primary control of the CO2 fertilization effect,"' Science (New York, N.Y.), vol. 355, no. 6323. p. 358, 2017.

[18] S. Zhang, L. Wang, F. Ma, X. Zhang, and D. Fu, "Arbuscular mycorrhiza improved phosphorus efficiency in paddy fields," Ecol. Eng., vol. 95, pp. 64-72, 2016.

[19] L. Jin, Q. Wang, Q. Wang, X. Wang, and A. C. Gange, "Mycorrhizal-induced growth depression in plants," Symbiosis, vol. 72, no. 2. pp. 81-88, 2017.

[20] K. Jeong, N. Mattes, S. Catausan, J. H. Chin, U. Paszkowski, and S. Heuer, "Genetic diversity for mycorrhizal symbiosis and phosphate transporters in rice," J. Integr. Plant Biol., vol. 57, no. 11, pp. 969-979, 2015.

[21] H. Lambers et al., "How belowground interactions contribute to the coexistence of mycorrhizal and non-mycorrhizal species in severely phosphorus-impoverished hyperdiverse ecosystems," Plant and Soil, pp. 1-23, 2017.

[22] D. M. Eissenstat, J. M. Kucharski, M. Zadworny, T. S. Adams, and R. T. Koide, "Linking root traits to nutrient foraging in arbuscular mycorrhizal trees in a temperate forest," New Phytol., vol. 208, no. 1, pp. 114-124, Oct. 2015.

[23] E. Paterson, A. Sim, J. Davidson, and T. J. Daniell, "Arbuscular mycorrhizal hyphae promote priming of native soil organic matter mineralisation," Plant Soil, vol. 408, no. 1-2, pp. 243-254, Nov. 2016.

[24] H. Javot, R. V. Penmetsa, N. Terzaghi, D. R. Cook, and M. J. Harrison, “A Medicago truncatula phosphate transporter indispensable for the arbuscular mycorrhizal symbiosis.," Proc. Natl. Acad. Sci. U. S. A., vol. 104, no. 5, pp. 1720-1725, 2007.

[25] G. A. Hoysted et al., "A mycorrhizal revolution," Current Opinion in Plant Biology, vol. 44. pp. 1-6, 2018.

[26] W. Chen, R. T. Koide, T. S. Adams, J. L. DeForest, L. Cheng, and D. M. Eissenstat, "Root morphology and mycorrhizal symbioses together shape nutrient foraging strategies of temperate trees," Proc. Natl. Acad. Sci., vol. 113, no. 31, pp. 8741-8746, 2016.

[27] N. Hidayati, Triadiati, and I. Anas, "Photosynthesis and Transpiration Rates of Rice 
Cultivated Under the System of Rice Intensification and the Effects on Growth and Yield," HAYATI J. Biosci., vol. 23, no. 2, pp. 67-72, 2016.

[28] K. Garbach, J. C. Milder, F. A. J. DeClerck, M. Montenegro de Wit, L. Driscoll, and B. Gemmill-Herren, "Examining multi-functionality for crop yield and ecosystem services in five systems of agroecological intensification," Int. J. Agric. Sustain., vol. 15, no. 1, pp. 11-28, 2017.

[29] E. T. Kiers, S. A. West, G. A. K. Wyatt, A. Gardner, H. Bücking, and G. D. A. Werner, "Misconceptions on the application of biological market theory to the mycorrhizal symbiosis," Nat. Plants, vol. 2, no. 5, p. 16063, May 2016.

[30] J. A. Bennett, H. Maherali, K. O. Reinhart, Y. Lekberg, M. M. Hart, and J. Klironomos, "Plant-soil feedbacks and mycorrhizal type influence temperate forest population dynamics," Science (80-. )., vol. 355, no. 6321, pp. 181-184, Jan. 2017.

[31] C. N. Daynes, D. J. Field, J. A. Saleeba, M. A. Cole, and P. A. McGee, "Development and stabilisation of soil structure via interactions between organic matter, arbuscular mycorrhizal fungi and plant roots," Soil Biol. Biochem., vol. 57, pp. 683-694, Feb. 2013.

[32] K. Garcia and S. D. Zimmermann, "The role of mycorrhizal associations in plant potassium nutrition," Front. Plant Sci., vol. 5, Jul. 2014.

[33] S. Firmin et al., "Arbuscular mycorrhizal fungal inoculation protects Miscanthus $\times$ giganteus against trace element toxicity in a highly metal-contaminated site," Sci. Total Environ., vol. 527-528, pp. 91-99, 2015.

[34] N. Wurzburger, E. N. J. Brookshire, M. L. McCormack, and R. A. Lankau, "Mycorrhizal fungi as drivers and modulators of terrestrial ecosystem processes," New Phytol., vol. 213, no. 3, pp. 996-999, 2017. 